\title{
Pemanfaatan keong mas (Pomacea canaliculata) sebagai pakan segar untuk mempercepat pertumbuhan benih ikan lele dumbo (Clarias gariepinus) [Utilization of golden snails (Pomacea canaliculata) as fresh feed to accelerate the seeds growth of African catfish (Clarias gariepinus)]
}

\author{
Rinaldi ${ }^{1}$, Azrul Ridha ${ }^{{ }^{*}}$
}

\section{${ }^{1}$ Program Studi Akuakultur, Fakultas Pertanian Universitas Almuslim. Jln. Almuslim Matangglumpangdua, Bireuen-Aceh}

ABSTRACT | This study aims to increase the growth and feed efficiency of catfish seeds by giving golden snails in the form of fresh feed as additional feed. The experimental design used was a completely randomized design (CRD) with 4 treatments with 3 replications, namely $25 \%$ fresh gold snail meat and $75 \%$ commercial feed, $50 \%$ fresh gold snail meat and 50\% commercial feed, $100 \%$ gold snail meat and $100 \%$ feed. commercial (control). The parameters observed in this study were the addition of fish body weight and length, survival rate and feed efficiency. The quality data observed were analyzed using the $\mathrm{F}$ test (Anova). The results showed that the treatment of golden snails had a significant effect $(\mathrm{P}<0.01)$ on weight gain, length addition and feed efficiency of milkfish fry. The highest weight gain was found in the $100 \%$ gold snail meat feed treatment of 2.23 grams and the lowest was in the $100 \%$ commercial feed (control) feed treatment of 1.5 grams. The highest increase in length was found in the $100 \%$ feed treatment of golden snail meat of $3.14 \mathrm{~cm}$ and the lowest was in the 100\% commercial feed (control) of $2.14 \mathrm{~cm}$. The highest feed efficiency was found in the $100 \%$ feed treatment of golden snail meat at $13.15 \%$ and the lowest in the $100 \%$ commercial feed treatment (control) at $11.41 \%$. The highest survival rate was found in the $100 \%$ commercial feed (control) feed treatment (control) at $90 \%$ and the lowest in the 100\% gold snail meat diet treatment at 63.3\%.

Key words | Golden snails, growth and survival, seeds of African catfish (Clarias gariepinus)

\begin{abstract}
ABSTRAK | Penelitian ini bertujuan untuk meningkatkan pertumbuhan dan efisiensi pakan pada benih ikan lele dengan pemberian keong mas dalam bentuk pakan segar sebagai pakan tambahan. Rancangan percobaan yang digunakan Rancangan Acak Lengkap (RAL) dengan 4 perlakuan 3 ulangan, yaitu $25 \%$ daging keong mas segar dan $75 \%$ pakan komersil, $50 \%$ daging keong mas segar dan $50 \%$ pakan komersil, $100 \%$ daging keong mas dan $100 \%$ pakan komersil (kontrol). Parameter yang diamati dalam penelitian ini adalah penambahan berat dan panjang tubuh ikan, tingkat kelangsungan hidup dan efisiensi pakan. Data kualitas yang diamati dianalisis dengan uji F (Anova). Hasil penelitian menunjukkan bahwa perlakuan keong mas berpengaruh nyata $(\mathrm{P}<0,01)$ terhadap penambahan berat, penambahan panjang dan efisiensi pakan benih ikan bandeng. Penambahan berat tertinggi terdapat pada perlakuan pakan 100\% daging keong mas sebesar 2,23 gram dan terendah pada perlakuan pakan $100 \%$ pakan komersil (kontrol) sebesar 1,5 gram. Penambahan panjang tertinggi terdapat pada perlakuan pakan $100 \%$ daging keong mas sebesar $3,14 \mathrm{~cm}$ dan terendah pada perlakuan pakan $100 \%$ pakan komersil (kontrol) sebesar 2,14 cm. Efisiensi pakan tertinggi ditemukan pada perlakuan pakan 100\% daging keong mas sebesar $13,15 \%$ dan terendah pada perlakuan pakan 100\% komersil (kontrol) sebesar 11,41\%. Tingkat kelangsungan hidup tertinggi ditemukan pada perlakuan pakan $100 \%$ pakan komersil (kontrol) sebesar 90\% dan terendah pada perlakuan pakan $100 \%$ daging keong mas sebesar $63,3 \%$.
\end{abstract}

Kata kunci | Keong mas, pertumbuhan dan kelangsungan hidup, benih ikan lele dumbo (Clarias gariepinus)

Received | 12 Mei 2021, Accepted | 24 Mei 2021, Published | 31 Mei 2021.

*Koresponden | Azrul Ridha, Program Studi Akuakultur, Fakultas Pertanian Universitas Almuslim. Jln. Almuslim Matangglumpangdua, Bireuen-Aceh. Email: arida109@gmail.com

Kutipan | Rinaldi, R., \& Ridha, A. (2021). Pemanfaatan keong mas (Pomacea canaliculata) sebagai pakan segar untuk mempercepat pertumbuhan benih ikan lele dumbo (Clarias gariepinus). Arwana: Jurnal Ilmiah Program Studi Perairan, 3(1), 28-35.

p-ISSN (Media Cetak) | 2657-0254

e-ISSN (Media Online) | 2797-3530

BY SA $($ C) 2021 Oleh authors. Arwana: Jurnal Ilmiah Program Studi Perairan. Artikel ini bersifat open access yang
didistribusikan di bawah syarat dan ketentuan Creative Commons Attribution-ShareAlike 4.0 International License. 


\section{PENDAHULUAN}

Perikanan budidaya telah banyak berkembang pada saat ini di wilayah Aceh, khususnya Kabupaten Bireuen. Budidaya ikan merupakan salah satu usaha masyarakat untuk meningkatkan penghasilan dan kesejahteraan ekonomi. Ikan lele dumbo (Clarias gariepinus) merupakan salah satu komoditas perikanan yang telah banyak dibudidayakan oleh masyarakat di Kabupaten Bireuen. Ikan lele banyak dikembangkan sebagai jenis makanan yang beragam di Kabupaten Bireuen, misalnya pecel lele, lele penyet, lele sale dan kerupuk lele. Ikan lele menjadi komoditas yang banyak dipilih masyarakat petani ikan karena mudah dalam tahapan budidaya, ikan lele dapat hidup pada kualitas air yang buruk dan dengan padat tebar yang tinggi.

Seperti budidaya lainnya, pertumbuhan lele dumbo dipengaruhi oleh kualitas air dan manajemen pakan. Pakan merupakan salah satu faktor yang paling berpengaruh terhadap pertumbuhan dan kelangsungan hidup ikan lele. Ketersediaan pakan yang memenuhi nilai gizi yang sesuai untuk kebutuhan ikan lele menjadi salah satu syarat yang wajib untuk mempercepat pertumbuhan. Pada umumnya, efisiensi pakan dan pertumbuhan dijadikan dasar untuk pemilihan kandungan kadar protein yang tinggi dalam pakan. Namun, disisi lain, efisiensi pakan dan pertumbuhan belum tentu akan meningkatkan keuntungan karena untuk mendapatkan pertumbuhan ikan yang tinggi, dibutuhkan pakan yang berkualitas dan tentunya memerlukan biaya yang lebih besar.

Mahalnya harga pakan ikan dan rendahnya harga jual ikan air tawar merupakan masalah besar dalam pengembangan budidaya ikan termasuk lele. Salah satu cara yang dapat digunakan untuk menekan biaya pakan adalah dengan memanfaatkan pakan yang ada di alam dengan harga ekonomis yang rendah, tetapi mengandung nilai gizi yang tinggi terutama kandungan protein. Salah satu pakan alternatif yang dapat dijadikan sebagai pakan tambahan untuk menunjang pertumbuhan ikan lele adalah keong mas. Keong mas dapat digunakan sebagai pakan tambahan untuk memenuhi kebutuhan gizi ikan lele terutama kebutuhan protein.

Keong mas (Pomacea canaliculata) yang banyak terdapat di sawah dan menjadi musuh petani mengandung nilai gizi yang tinggi dengan kandungan protein yang sesuai untuk pertumbuhan ikan. Keong mas tersedia disepanjang tahun di kawasan berair, seperti sungai dan aliran irigasi. Keong mas memiliki kandungan nilai gizi yang baik untuk pertumbuhan ikan lele dengan kadar protein yang terkandung dalam keong mas mencapai 51, $8 \%$ (Tarigan, 2008).

Kandungan protein biasanya yang dijadikan patokan karena kandungan ini yang paling mahal dan sangat menentukan terhadap kualitas pakan ikan. Kebutuhan protein ikan lele untuk pertumbuhannya mencapai 40\% (Mahyudin, 2013). Hal tersebut sesuai dengan kadar protein yang terdapat pada keong mas. selain itu, penggunaan keong mas sebagai pakan tambahan pada ikan lele dalam bentuk pakan segar dapat menurunkan biaya produksi ikan lele. Karena keong mas merupakan hama pertanian padi dan dapat diperoleh dengan harga yang sangat murah bahkan cuma-cuma. Dari latar belakang diatas, penulis ingin meneliti pertumbuhan dan efisiensi pakan pada benih ikan lele yang diberikan keong mas dalam bentuk pakan segar.

Keong mas memiliki kandungan protein yang sesuai dengan kebutuhan protein untuk pertumbuhan benih ikan lele, sehingga dapat digunakan sebagai pakan tambahan bagi benih ikan lele untuk meningkatkan pertumbuhan dan menekan biaya pakan. Tujuan dari penelitian ini adalah untuk meningkatkan pertumbuhan dan efisiensi pakan pada benih ikan lele dengan pemberian keong mas dalam bentuk pakan segar sebagai pakan tambahan.

\section{BAHAN DAN METODE}

\section{Waktu dan Tempat Penelitian}

Penelitian ini telah dilaksanakan pada bulan Februari - Maret 2016 di laboratorium Budidaya Perairan Universitas Almuslim. Adapun rancangan percobaan yang digunakan dalam penelitian ini adalah Rancangan Acak Lengkap dengan 4 (empat) perlakuan dan 3 (tiga) kali ulangan. Adapun rincian perlakuan yang akan diberikan pada penelitian ini adalah (Hendrawati, 2011): Perlakuan A : $25 \%$ daging keong mas segar dan $75 \%$ pakan komersil, Perlakuan B : $50 \%$ daging keong mas segar dan $50 \%$ pakan komersil, Perlakuan C : 100\% daging keong mas, Perlakuan D : Kontrol (100 \% pakan komersil). 


\section{Persiapan Wadah}

Wadah yang digunakan dalam penelitian ini adalah Aquarium ukuran 20x40x40 cm. Akuarium dicuci terlebih dahulu dan dikeringkan, kemudian bak diisi dengan air sebanyak 25 liter. Setelah diisi dengan air, akuarium dipasangkan peralatan aerasi, kemudian air dibiarkan selama 24 jam. Setelah 24 jam baru dimasukan ikan dalam akuarium secara pelahan-lahan.

\section{Persiapan Ikan}

Ikan lele yang digunakan diambil dari hasil pembenihan petani ikan di Kabupaten Bireuen. Benih ikan lele yang digunakan adalah benih ikan lele dengan ukuran panjang 5-7 cm dan berat 1,6 gram sebanyak 160 ekor. Ikan yang digunakan adalah ikan yang sehat dan tidak menunjukan gejala serangan penyakit, seperti bercak merah dan luka pada bagian tubuh, nafsu makan ikan tinggi dan berenang lincah. Ikan diaklimatisasi terlebih dahulu selama 3 hari sebelum diberikan perlakuan. Selama proses aklimatisasi ikan tetap diberikan pakan untuk menjaga kelangsungan hidup benih ikan lele yang dipelihara.

\section{Pesiapan Keong Mas}

Keong mas direbus terlebih dahulu selama 5 menit dan tidak sampai mendidih agar kadar nutrisi yang terkandung dalam daging keong mas tidak menurun. Tujuan perebusan adalah untuk mempermudah pengeluaran daging dari cangkang. Daging yang telah dikeluarkan dari cangkang dicuci sampai bersih kemudian dicincang halus sesuai dengan bukaan mulut benih ikan lele dengan ukuran sebesar $2 \mathrm{~mm}$.

\section{Pemberian Pakan}

Pemberian pakan dilakukan dengan frekuensi 3 kali sehari pada pagi, siang dan sore hari dengan persentase $5 \%$ dari biomas benih ikan lele (Mudjiman, 2008). Pada perlakuan A dan B dengan pemberian pakan keong mas segar dan pakan komersil. Analisa komposisi nutrisinya pakan komersil disajikan dalam tabel berikut ini:

Tabel 1. Analisa komposisi nutrisinya pakan komersil yang digunakan dalam penelitian

\begin{tabular}{ll}
\hline Protein Kasar min & $35 \%$ \\
Lemak Kasar min & $2 \%$ \\
Serat Kasar max & $3 \%$ \\
Abu Kasar max & $13 \%$ \\
Kadar Air max & $12 \%$ \\
\hline
\end{tabular}

Pemberian pakan komersil dilakukan setelah pemberian pakan keong mas segar sesuai dengan persentase yang telah ditentukan. Pada perlakuan $\mathrm{C}$ dilakukan pemberian $100 \%$ pakan keong mas segar dan tanpa pakan komersil. Sedangkan untuk perlakuan D tanpa pemberian pakan keong mas segar, pakan yang diberikan adalah $100 \%$ pakan komersil. Jumlah pakan keong mas yang dibutuhkan untuk penelitian ini adalah \pm 600 gram/ 30 hari. Jumlah pakan untuk setiap pemberian pakan membutuhkan dengan jumlah yang berkisar antara $\pm 0,26$ gram sampai $\pm 0,42$ gram.

\section{Pemeliharaan}

Lama waktu pemeliharaan yang dilakukan pada penelitian ini adalah selama 30 hari (1 bulan). Selama pemeliharaan dilakukan pengukuran terhadap pertumbuhan berat dan panjang, efisiensi pakan setiap 10 hari sekali dan menghitung tingkat kelangsungan hidup pada akhir penelitian.

\section{Pertumbuhan}

Pertumbuhan merupakan tahapan penambahan berat dan panjang tubuh ikan selama pemeliharaan. Perhitungan pertambahan berat tubuh dapat dihitung dengan menggunakan rumus dari Mahyudin (2013), yaitu sebagai berikut:

\section{$\mathrm{Wm}=\mathrm{Wt}-\mathrm{Wo}$}

Keterangan :

$\mathrm{Wm}$ : Total penambahan berat tubuh ikan (gram) Wt : Berat akhir ikan (gram), Wo : Berat awal ikan (gram)

Ukuran panjang benih adalah panjang total yakni jarak antara ujung mulut hingga ujung sirip ekor ikan. Pengukuran panjang total dapat dilakukan dengan menggunakan rumus Mahyudin (2013), yaitu :

$$
\mathbf{P m}=\mathbf{P t}-\mathbf{P o}
$$

Keterangan :

$\mathrm{Pm}=$ Pertambahan panjang ikan $(\mathrm{cm}), \quad \mathrm{Pt}=$ Pertambahan panjang rata-rata benih pada akhir $(\mathrm{cm}) \mathrm{Po}_{\mathrm{O}}$ Panjang awal benih $(\mathrm{cm})$

\section{Kelangsungan Hidup}

Kelangsungan hidup ikan adalah persentase kelangsungan hidup ikan yang dihitung pada akhir penelitian yang dihitung dari total jumlah ikan yang tersisa pada akhir pemeliharaan. Tingkat kelangsungan hidup dapat dihitung 
dengan menggunakan rumus dari Mahyudin (2013), yaitu :

$$
\mathrm{SR}=\frac{\mathrm{Nt}}{\mathrm{No}} \times 100
$$

Keterangan:

SR: Tingkat kelangsungan hidup (\%), Nt : Jumlah ikan pada akhir (ekor), No :Jumlah ikan pada awal (ekor)

\section{Efisiensi Pakan}

Efisiensi pakan menunjukkan jumlah pakan yang dicerna oleh ikan nila merah untuk kebutuhan hidup dan pertumbuhanya, Efisiensi pakan dihitung berdasarkan biomassa ikan pada akhir dan awal penelitian dibandikan dengan jumlah pakan yang diberikan berdasarkan rumus Kordi (2009) yaitu:

$$
\mathbf{E}=\frac{(\mathbf{W t}+\mathbf{D})-\mathbf{W o}}{\mathbf{F}} \times 100
$$

Keterangan:

$\mathrm{E}=$ Efisiensi pemberian pakan (gram), Wt $=$ Bobot biomassa ikan lele pada akhir penelitian (gram), Wo = Bobot biomassa ikan lele pada awal penelitian (gram), D = Bobot ikan lele yang mati selama penelitian (gram), $\mathrm{F}=$ Jumlah pakan yang diberikan (gram)

\section{Analisa Data}

Data yang telah dikumpulkan kemudian dianalisis dengan analisis varian (ANOVA). Apabila perlakuan yang diberikan menunjukkan pengaruh yang nyata, maka diuji lanjut dengan Uji Beda Nyata Terkecil (BNT) dengan taraf kepercayaan $5 \%$ yang bertujuan untuk mengetahui konsentrasi perlakuan yang terbaik (Kusriningrum, 2008).

\section{HASIL}

\section{Pertumbuhan Berat dan Panjang}

Pertumbuhan pada ikan ditandai dengan bertambahnya ukuran tubuh ikan, pertambahan tubuh terjadi pada berat dan panjang ikan yang dipelihara. Hasil penelitian didapatkan pertumbuhan berat tertinggi pada ikan lele yang diberi pakan berbeda pada perlakuan $\mathrm{C}$ dengan pemberian $100 \%$ pakan segar keong mas sebesar 2,23 gram/ ekor (Gambar 1). Perbedaan pertumbuhan ikan lele yang diberikan pakan yang berbeda. Pertumbuhan berat yang paling tinggi terdapat pada perlakuan $\mathrm{C}$ dengan pemberian $100 \%$ pakan segar keong mas dan pertumbuhan berat yang paling rendah terdapat pada perlakuan $\mathrm{D}$ dengan pemberian 100\% pakan komersil. Hasil uji Anova pada nilai pertumbuhan berat ikan lele memperoleh hasil yang berbeda nyata dengan nilai Fhitung $>$ Ftabel 0,05. Sedangkan pada uji lanjut nilai pertumbuhan berat ikan lele diperoleh bahwa perlakuan A tidak berbeda dengan perlakuan B tetapi berbeda dengan perlakuan $\mathrm{C}$ dan $\mathrm{D}$.

Hasil penelitian didapatkan pertumbuhan panjang tertinggi pada ikan lele yang diberi pakan berbeda pada perlakuan $\mathrm{C}$ dengan pemberian $100 \%$ pakan segar keong mas sebesar 3,14 cm (Gambar 2).

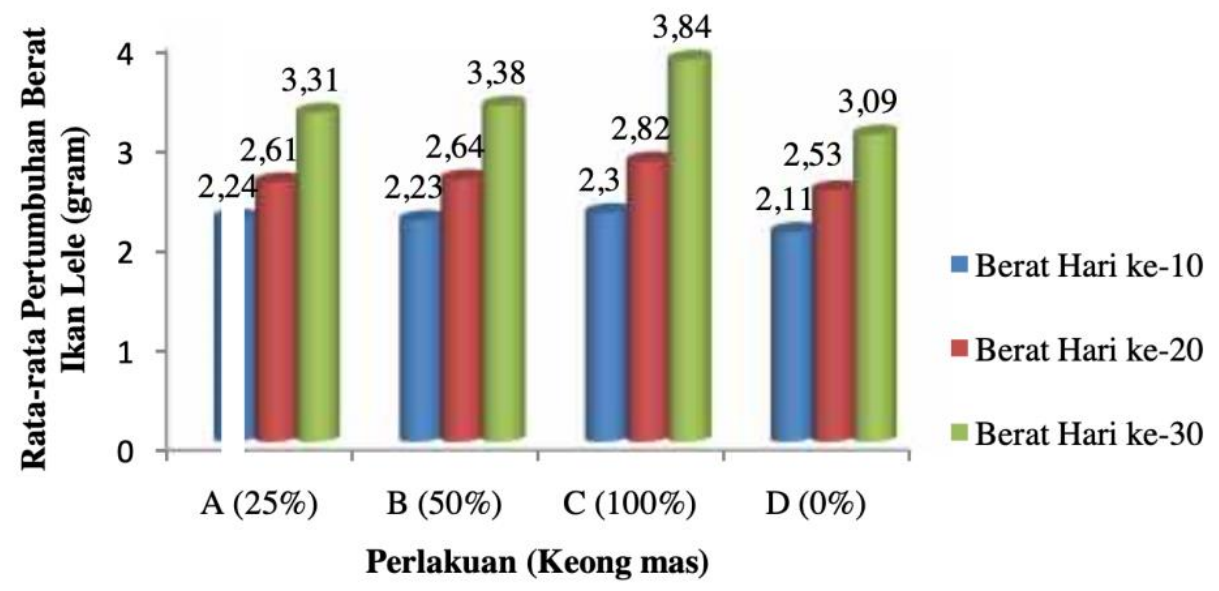

Gambar 1. Grafik Rata-rata Pertumbuhan Berat Ikan Lele 


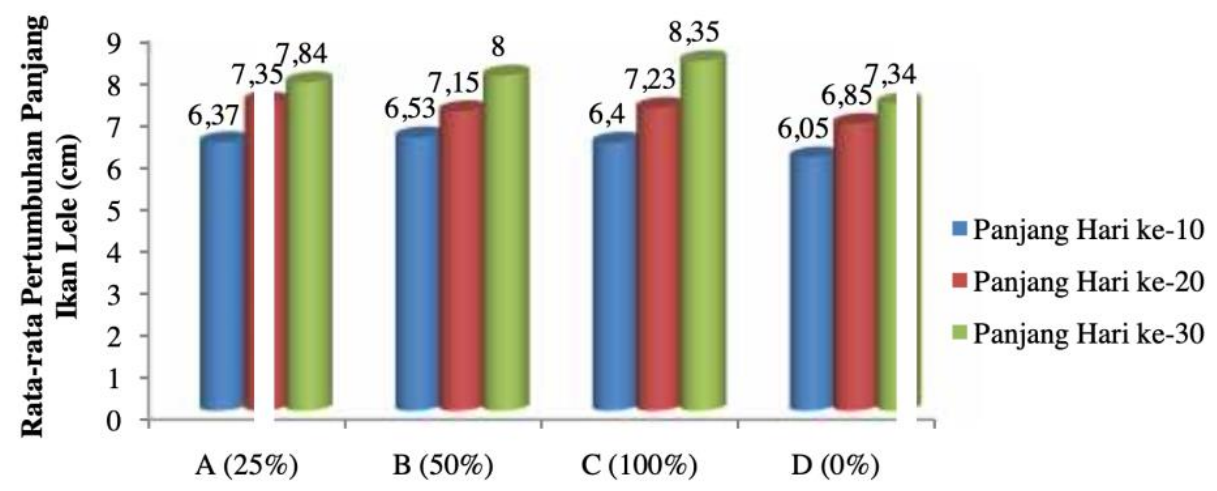

Gambar 2. Grafik Rata-rata Pertumbuhan Panjang Ikan lele

Rata-rata pertumbuhan panjang tubuh ikan lele yang diberi pakan yang berbeda yang paling tinggi terdapat pada perlakuan $\mathrm{C}$ dengan pemberian $100 \%$ pakan segar keong mas dan pertumbuhan panjang tubuh ikan lele yang paling rendah terdapat pada perlakuan D dengan pemberian $100 \%$ pakan komersil (Gambar 2). Hasil uji anova pada nilai pertumbuhan panjang tubuh ikan lele memperoleh hasil yang berbeda nyata dengan nilai Fhitung $>$ Ftabel 0,05. Sedangkan pada uji lanjut nilai pertumbuhan panjang tubuh ikan lele diperoleh bahwa perlakuan A tidak berbeda dengan perlakuan B tetapi berbeda dengan perlakuan $\mathrm{C}$ dan $\mathrm{D}$.

\section{Efisiensi Pakan}

Efisiensi pakan merupakan tingkat pemanfaatan pakan oleh ikan untuk pertumbuhannya. Nilai efisiensi pakan ikan lele yang diberikan pakan berbeda yang paling tinggi didapatkan pada perlakuan $\mathrm{C}$ dengan pemberian $100 \%$ pakan segar keong mas sebesar 13,15\% (Gambar 3).

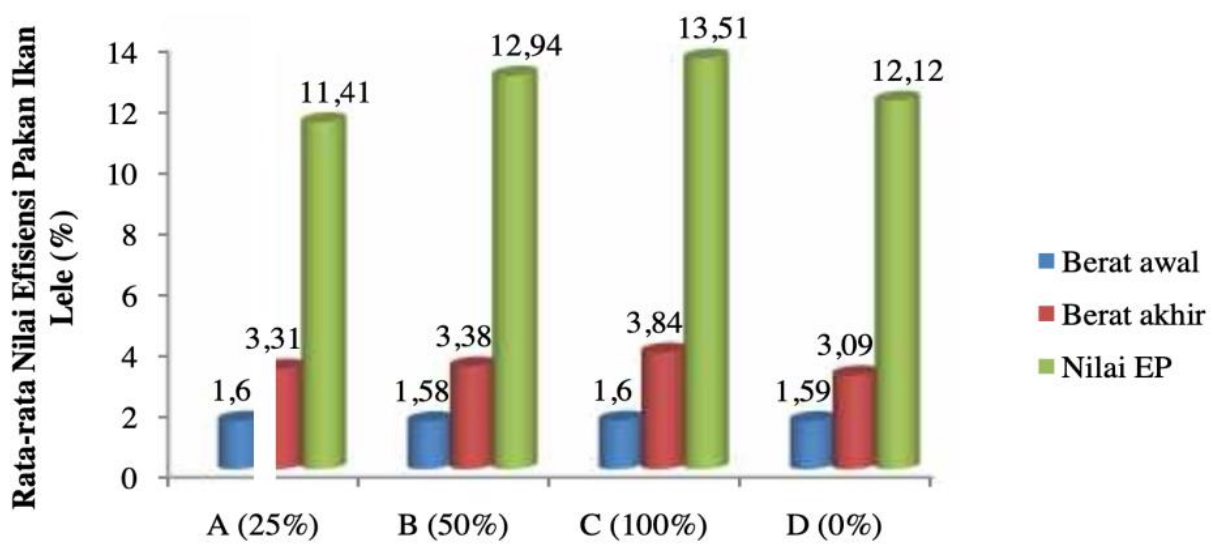

Perlakuan (Keong mas)

Gambar 3. Rata-rata Nilai Efisiensi Pakan Ikan Lele

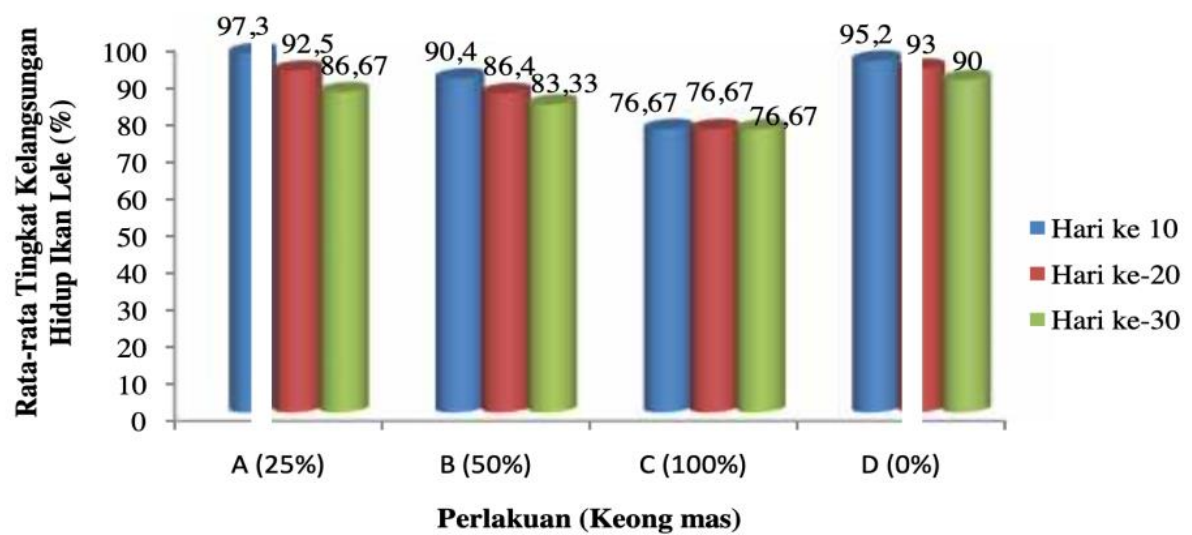

Gambar 4. Rata-rata Nilai Tingkat Kelangsungan Hidup Ikan Lele 
Dari Gambar 3. di atas dapat dilihat bahwa nilai efisiensi pakan yang paling tinggi terdapat pada perlakuan C dengan pemberian $100 \%$ pakan keong mas segar sebesar $13,15 \%$ dan nilai efisiensi pakan yang paling rendah terdapat pada perlakuan dengan pemberian keong mas segar $25 \%$ sebesar $11,41 \%$. Hasil uji anova nilai efisiensi pakan ikan lele yang diberikan pakan yang berbeda diperoleh hasil yang berbeda nyata dengan nilai Fhitung $>$ Ftabel 0,05 . Sedangkan pada uji lanjut nilai efisiensi pakan ikan lele yang diberi pakan yang berbeda diperoleh bahwa perlakuan A tidak berbeda dengan perlakuan B tetapi berbeda dengan perlakuan $\mathrm{C}$ dan $\mathrm{D}$, sedangkan perlakuan $\mathrm{B}$ tidak berbeda dengan perlakuan $\mathrm{C}$ tetapi berbeda dengan perlakuan $\mathrm{D}$.

\section{Tingkat Kelangsungan Hidup}

Nilai tingkat kelangsungan hidup ikan lele diperoleh dari perhitungan jumlah ikan lele yang ditebarkan pada awal pemeliharaan dan jumlah ikan yang masih hidup pada akhir pemeliharaan. Hasil perhitungan nilai tingkat kelangsungan hidup pada ikan lele, diperoleh hasil yang paling tinggi pada perlakuan D dengan pemberian $100 \%$ pakan komersil (Gambar 4). Dari Gambar 4. di atas dapat dilihat bahwa nilai tingkat kelangsungan hidup yang paling tinggi ada ikan lele yang diberikan pakan yang berbeda terdapat pada perlakuan $\mathrm{D}$ dengan pemberian $100 \%$ pakan komesil sebesar 90\%, sedangkan nilai tingkat kelangsungan hidup yang paling rendah terdaat pada perlakuan $\mathrm{C}$ dengan pemberian $100 \%$ pakan segar keong mas sebesar 76,67\%. Hasil uji Anova pada nilai tingkat kelangsungan hidup ikan lele yang diberikan pakan yang berbeda diperoleh hasil yang tidak berbeda nyata dengan nilai Fhitung $<$ Ftabel 0,05.

\section{PEMBAHASAN}

Hasil penelitian perhitungan nilai pertumbuhan berat tubuh pada ikan lele didapatkan hasil yang paling tinggi pada perlakuan $\mathrm{C}$ dengan pemberian $100 \%$ pakan keong mas segar sebesar 2,23 gram dan yang paling rendah didapatkan pada perlakuan D dengan pemberian $100 \%$ pakan komersil sebesar 1,5 gram. Nilai pertumbuhan panjang tubuh ikan lele yang paling tinggi terdapat pada perlakuan $\mathrm{C}$ dengan pemberian $100 \%$ pakan keong mas segar sebesar $3,14 \mathrm{~cm}$ dan pertumbuhan panjang ikan lele yang paling rendah terdapat pada pelakuan $\mathrm{D}$ dengan pemberian 100\% pakan komersil sebesar $2,14 \mathrm{~cm}$.

Pemberian pakan keong mas mempercepat pertumbuhan ikan lele dari berat dan panjang yang dibuktikan dengan nilai dari hasil penelitian. Tingginya nilai pertumbuhan ikan lele yang didapatkan diduga oleh kandungan potein daging keong mas yang lebih tinggi yaitu sebesar 51,8\% (Tarigan, 2008), dibandingkan dengan protein yang terkandung dalam pakan komersil yaitu sebesar $\pm 25 \%$. Paiko et al. (2010), menyatakan bahwa komponen protein dalam pakan beserta rasio energi pakan juga berpengaruh terhadap pertumbuhan dan kelangsungan hidup benih ikan.

Hasil pengukuran parameter efisiensi pakan ikan lele yang diberikan pakan yang berbeda menunjukkan nilai efisiensi pakan yang paling tinggi terdapat pada perlakuan dengan pemberian $100 \%$ pakan keong mas segar sebesar $13,15 \%$. Sedangkan nilai efisiensi pakan ikan lele yang paling rendah terdapat pada perlakuan dengan pemberian $25 \%$ pakan keong mas segar sebesar 11,41\%. Agusnaidi (2020) menunjukkan bahwa pemberian cacing sutera dengan persentase adlibitum (10\%) memperoleh pertumbuhan benih ikan gabus yang lebih cepat. Tingginya nilai efisiensi pakan menggambarkan tingginya nilai pemanfaatan pakan yang diberikan pada ikan lele untuk pertumbuhannya.

Dari nilai efisiensi pakan ikan lele yang diperoleh pada perlakuan dengan pemberian $100 \%$ pakan keong mas segar sebesar $13,15 \%$, maka dengan pemberian pakan sebanyak 100 gram didapatkan pertambahan berat tubuh ikan lele sebesar 13,15 gram. Sedangkan nilai efisiensi pakan yang didapatkan pada perlakuan dengan pemberian $25 \%$ pakan keong mas segar sebesar $11,41 \%$, maka dengan pemberian pakan sebanyak $1 \mathrm{~kg}$ didapatkan penambahan berat tubuh ikan lele sebesar 11,41gram. Menurut Mahyudin (2013), sebagian dari makanan yang dimakan berubah menjadi energi yang digunakan untuk aktivitas hidup dan sebagian keluar dari tubuh.

Pakan yang dimakan ikan akan diproses dalam tubuh dan unsur-unsur nutrisi dan vitamin atau gizinya akan diserap untuk dimanfaatkan membangun jaringan sehingga terjadi pertumbuhan (SNI, 2006). Vitamin C berpengaruh nyata terhadap pertambahan 
panjang, pertambahan berat dan efisiensi pakan benih ikan betok (Fitriani dan Akmal, 2020). Efesiensi pemberian pakan dengan penambahan vitamin $\mathrm{E}$ sangat berpengaruh terhadap pertumbuhan benih udang windu (Mukhlis et al., 2020).

Kemampuan daya cerna ikan terhadap suatu pakan dipengaruhi oleh beberapa faktor, yaitu sifat kimia air, suhu air, jenis pakan, ukuran dan umur ikan, kandungan nutrisi pakan, frekuensi pemberian pakan serta jumlah dan macam enzim pencernaan yang terdapat dalam saluran pencernaan pakan (Yanti, 2013). Menurut Setiawati (2003), jumlah pakan yang mampu dikonsumsi ikan setiap harinya merupakan salah satu faktor yang mempengaruhi potensi ikan untuk tumbuh secara maksimal dan laju konsumsi makanan harian berhubungan erat dengan kapasitas dan pengosongan perut. Menurut Khairil et al. (2020) kulit kakao pada pakan ikan nila merah berpengaruh sangat nyata terhadap kelangsungan hidup, laju pertumbuhan, bobot dan efesiensi pemberian pakan

Hasil penelitian diperoleh nilai tingkat kelangsungan hidup ikan lele yang paling tinggi pada perlakuan D dengan pemberian 100\% pakan komersil sebesar 90\% dan tingkat kelangsungan hidup yang paling rendah didapatkan pada perlakuan $\mathrm{C}$ dengan pemberian $100 \%$ pakan keong mas sebesar $76,67 \%$. Nilai tingkat kelangsungan hidup yang didapatkan dari hasil penelitian merupakan nilai tingkat kelangsungan hidup yang standar bagi ikan lele seperti yang dikemukakan oleh Suyanto (2004), bahwa angka mortalitas (kematian) pada pemeliharaan ikan lele yang mencapai $30-50 \%$ masih dianggap normal. Pemberian suspensi kuning telur Ayam, Itik, dan Puyuh sangat berbeda nyata terhadap panjang dan pertumbuhan ikan lele (Helmi, 2020).

Dari hasil penelitian yang dilakukan, didapatkan kematian pada ikan lele terjadi pada saat awal pemeliharaan. Hal ini diduga akibat stres yang terjadi pada ikan karena singkatnya masa aklimatisasi, sehingga tidak semua ikan dapat menyesuaikan diri dengan pakan yang diberikan untuk penelitian dan lingkungan baru. Ikan yang stress karena perubahan lingkungan tidak memiliki nafsu makan, sehingga akan mati setelah beberapa hari. Menurut Khairuman (2010), Perubahan lingkungan yang mendadak dapat membuat ikan menjadi stress, oleh karena itu kualitas air harus selalu dikontrol selama proses kegiatan budidaya ikan.

\section{KESIMPULAN}

Nilai pertumbuhan dan efisiensi pakan ikan lele yang paling tinggi didapatkan pada perlakuan $\mathrm{C}$ dengan pemberian $100 \%$ pakan keong mas segar dengan hasi uji anava memberikan pengaruh yang berbeda nyata terhadap perlakuan A, B dan D dengan nilai Fhitung > Ftabel 0,05. Untuk tingkat kelangsungan hidup yang paling tinggi terdapat pada perlakuan $\mathrm{D}$ dengan pemberian 100\% pakan komersil, tetapi tidak berpengaruh nyata terhadap perlakuan $\mathrm{A}, \mathrm{B}$ dan $\mathrm{C}$ dengan uji Anova. Pemberian pakan keong mas segar untuk ikan lele dapat meningkatkan pertumbuhan dan efisiensi pakan ikan lele.

\section{DAFTAR PUSTAKA}

Agusnaidi, A. (2020). Domestikasi benih ikan gabus (Channa striata) dengan pemberian pakan cacing sutera (Tubifex sp.). Arwana: Jurnal Ilmiah Program Studi Perairan, 2(1), 53-62.

Aliyu-Paiko, M., Hashim, R., \& Shu-Chien, A. C. (2010). Influence of dietary lipid/protein ratio on survival, growth, body indices and digestive lipase activity in Snakehead (Channa striatus, Bloch 1793) fry reared in re-circulating water system. Aquaculture Nutrition, 16(5), 466-474.

Fitriani, R., \& Akmal, Y. (2020). Penambahan Vitamin C pada pakan pelet untuk pertumbuhan benih ikan betok (Anabas testudineus). Arwana: Jurnal Ilmiah Program Studi Perairan, 2(2), 136-142.

Helmi, S. (2020). Pengaruh pemberian suspensi kuning telur (ayam, itik, dan puyuh) terhadap pertumbuhan larva ikan lele dumbo (Clarias gariepinus). Arwana: Jurnal Ilmiah Program Studi Perairan, 2(2), 118-122.

Indonesia, S. N. (2006). Pakan Buatan untuk Ikan Lele (Clarias gariepinus) pada Budidaya Intensif. SNI Pakan Buatan untuk Ikan Lele (Clarias gariepinus) pada Budidaya Intensif.

Khairil, K., Nazarah, I., \& Hakim, S. (2020). Pemanfaatan kulit kakao sebagai bahan baku pakan ikan nila merah (Oreochromis sp). Arwana: Jurnal Ilmiah Program Studi Perairan, 2(1), 38-45.

Khairuman, S. P. (2010). Budidaya Ikan Lele Dumbo di Kolam Terpal. Agromedia. Jakarta, 84.

Kordi, G. (2009). Budidaya Perairan Jilid 2. Bandung: PT Citra Aditya Bakti.

Kusriningrum, R. S. (2008). Buku Ajar Perancangan 
Percobaan. Fakultas kedokteran Hewan Universitas Airlangga, Dani Abadi, Surabaya, 65-125.

Mahyudin, K., \& S PI, M. M. (2013). Panduan lengkap agribisnis Lele. Niaga Swadaya.

Mudjiman, A. (2008). Kepelbagaian makanan ikan. Kuala Lumpur: Synergy Media,[200-?]..

Mukhlis, M., Humairani, R., Akmal, Y., \& Irfannur, I. (2020). Efektifitas penambahan Vitamin E pada pakan dalam meningkatkan pertumbuhan benih udang windu (Penaeus monodon). Arwana: Jurnal Ilmiah Program Studi Perairan, 2(2), 123-129.

Setiawati, M., \& Suprayudi, M. A. (2003). Pertumbuhan dan efisiensi pakan ikan nila merah (Oreochromis sp.) yang dipelihara pada media bersalinitas. Jurnal Akuakultur
Indonesia, 2(1), 27-30.f

Suyanto, N. S. R. (2004). Budidaya Ikan Lele (ed. Revisis). Niaga Swadaya.

Tarigan, S. J. B. (2008). Pemanfaatan Tepung Keong Mas Sebagai Substitusi Tepung Ikan dalam Ransum Terhadap Performans Kelinci Jantan Lepas Sapih. Skripsi. Departemen Peternakan Fakultas Pertanian. Universitas Sumatera Utara. Medan.

Yanti, Z., \& Muchlisin, Z. A. (2013). Pertumbuhan dan kelangsungan hidup benih ikan nila (Oreochromis niloticus) pada beberapa konsentrasi tepung daun jaloh (Salix tetrasperma) dalam pakan. DEPIK Jurnal Ilmu-Ilmu Perairan, Pesisir dan Perikanan, 2(1). 